\title{
Mixed connective tissue disease with associated glomerulonephritis and hypocomplementaemia
}

\author{
T. G. PALFERMAN* \\ M.B., M.R.C.P., D.C.H. \\ C. S. McIntosh $\dagger$ \\ M.D., M.R.C.P. \\ M. KERSHAW $\ddagger$ \\ MB. B.S. \\ *Westminster Hospital, London, S.W.1, †Queen Mary's Hospital, Roehampton, S.W.15, and \\ $\ddagger$ Department of Pathology, St Mary’s Hospital Medical School, London
}

\begin{abstract}
Summary
Mixed connective tissue disease is an increasingly recognized entity in which renal disease is thought to be unusual and associated hypocomplementaemia even more uncommon. A patient is described who had both these features and who also illustrates many of the characteristic features of this syndrome. The response to steroids of the systemic sclerosis component is well shown and an additional feature of interest is the family history of other connective tissue diseases.
\end{abstract}

\section{Introduction}

The term mixed connective tissue disease (MCTD) was proposed by Sharp et al. (1972) for a disease entity combining, in varying proportions, features of systemic lupus erythematosus (SLE), progressive systemic sclerosis (PSS) and polymyositis. This syndrome is characterized by the presence of a saline extractable nuclear antigen (ENA) believed to be predominantly ribonucleoprotein (RNP) and sensitive to ribonuclease (RNAase) digestion. Other findings include a strongly positive anti-nuclear factor (ANF) exhibiting a speckled immunofluorescent pattern and with normal DNA binding. Serum complement levels are usually normal or elevated, renal involvement believed rare. It has been considered to run a more benign course than SLE or systemic sclerosis alone and, unlike the latter, shows a good response to steroids. Described here is a case of MCTD with histologically-proved associated glomerulonephritis and persistent hypocomplementaemia.

\section{Case report}

A 41-year-old Venezuelan female was referred in September 1976 with an 8-month history of Raynaud's phenomenon, associated with transient arthralgia of wrists, elbows and shoulders responsive

* Present address: Dept Rheumatology, St Thomas Hospital, London SE7 E8. to phenylbutazone. Two sisters in Venezuela were said to have suffered from SLE, one of whom died as a result of the disease.

On examination, her fingers and toes were cold, white and numb but there was no other significant abnormality and there was no evidence of an arthropathy.

Investigations: $\mathrm{Hb}, 14.4 \mathrm{~g} / \mathrm{dl} ; \mathrm{WBC}, 5.9 \times 10^{9} / \mathrm{l}$; ESR $18 \mathrm{~mm} / \mathrm{hr}$ (Westergren); urea, $4.5 \mathrm{mmol} / \mathrm{l}$; total protein, $89 \mathrm{~g} / \mathrm{l}$; ANF showed a speckled immunofluorescence, positive 1:20000; DNA binding, $12 \mu / \mathrm{ml}$ (normal, <25). No L.E. cells were seen in peripheral blood preparations on 2 occasions.

It was considered likely, at this stage, that she had SLE, and she was regularly reviewed as an outpatient. Over the next 18 months, her joints were intermittently painful but her DNA binding remained low.

In February 1978 she was admitted to hospital complaining of shortness of breath. Examination on this occasion revealed sclerodactyly, posterior nail fold, telangiectasia, and a facial and neck rash all suggestive of PSS and verified by a dermatologist. There were also bilateral cervical lymphadenopathy and crackles at both lung bases.

Further investigations showed an ESR of 56 $\mathrm{mm} / \mathrm{hr}$; total protein, $100 \mathrm{~g} / \mathrm{l}$ with polyclonal globulin increase. X-ray of chest showed patchy infiltration, and of hands, no abnormality. Barium swallow remained in a dilated oesophagus when the patient was supine and no peristalsis was observed. Respiratory function tests (predicted normals in brackets): FVC, 1.85 litre (2.8); FEV $_{1}, 1.80$ litre (2.4); $\mathrm{FEV}_{1} / \mathrm{FVC}, 97 \%(85 \%)$; slow VC, 1.9 litre (2.86); FRC 1.91 litre (2.12); TLC, 3.2 litres (4.6); and $D_{\mathrm{L}, \text { CO }} 20.3 \mathrm{ml} / \mathrm{min} / \mathrm{mmHg}(21.9)$ showing therefore a restrictive defect. The ANF was as before; and DNA binding, $7 \mu / \mathrm{ml} ; \mathrm{C}_{3}, 0.4 \mathrm{~g} / \mathrm{l}$ (normal, 0.7-1.7); $\mathrm{C}_{4}, 0 \cdot 16 \mathrm{~g} / \mathrm{l}$ (normal $0 \cdot 1-0 \cdot 7$ ) repeated after 2 weeks 
with identical results. The serum creatinine, $66 \mu \mathrm{mol} / 1$ (normal, 50-140); urea, $5.2 \mathrm{mmol} / 1 ; 24-\mathrm{hr}$ urinary protein excretion, $0.08 \mathrm{~g} / \mathrm{l}$. Transbronchial lung biopsy showed histological changes consistent with PSS.

In the light of these findings mixed connective tissue disease was suspected and an extractable nuclear antigen (ENA) consisting entirely of RNP sensitive to RNAase digestion was found to be positive confirming the clinical diagnosis.

Her condition rapidly improved in hospital on symptomatic treatment and she was allowed home. After one month another practitioner prescribed prednisolone at an initial dose of $10 \mathrm{mg} /$ day rapidly reducing to nil over 2 weeks, on which she further improved.

In June 1978 she was re-admitted with sore throat, cervical lymphadenopathy and increasingly painful hands. On this occasion the ESR was $109 \mathrm{~mm} / \mathrm{hr}$; total protein, $109 \mathrm{~g} / 1$; respiratory function tests (predicted normals as before): FVC, $1 \cdot 19$ litre; $\mathrm{FEV}_{1}$, 1.13 litre; $\mathrm{FEV}_{1} / \mathrm{FVC}, 95 \%$; slow VC, 1.30 litre; FRC, 1.68 litre; TLC, 2.49 litres; DL,Co, 8.1 $\mathrm{ml} / \mathrm{min} / \mathrm{mmHg}$, thus showing an increased restrictive pattern. $\mathrm{C}_{3}, 0.03 \mathrm{~g} / \mathrm{l} ; \mathrm{C}_{4}, 0.1 \mathrm{~g} / \mathrm{l}$; serum creatinine well within the normal range $105 \mu \mathrm{mol} / 1$; creatinine clearance, $79 \mathrm{ml} / \mathrm{min}$. Proteinuria was detected on routine ward testing with a 24-hr urinary excretion of $0.59 \mathrm{~g}$.

In view of persistently low serum complement levels and increased 24-hr urinary protein excretion a percutaneous right renal biopsy was performed. This showed a diffuse mesangial proliferative glomerulonephritis with segmental increase in mesangial cells and polymorphs and capillary wall deposits of $\mathrm{C}_{3}$ and large granules of IgG (Figs 1, 2).

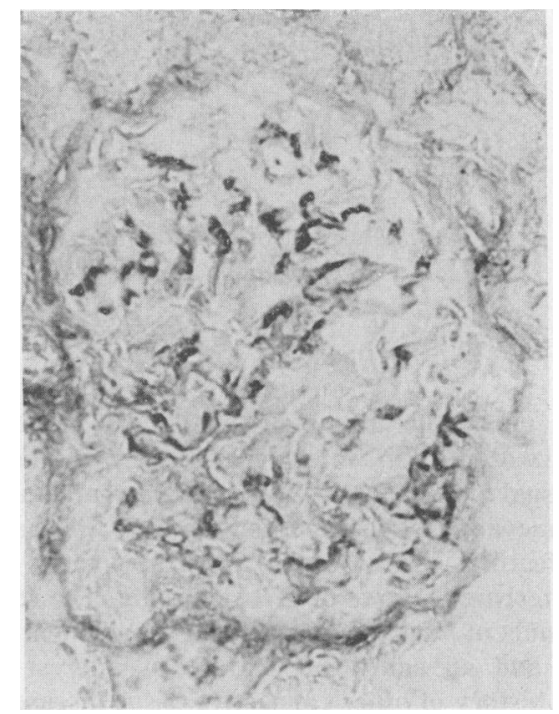

FIG. 1. Glomerulus containing dark deposits of reaction product in the mesangium (frozen section treated with horse radish peroxidase-labelled antibody to human $C_{3}$. $\times 200$ ).

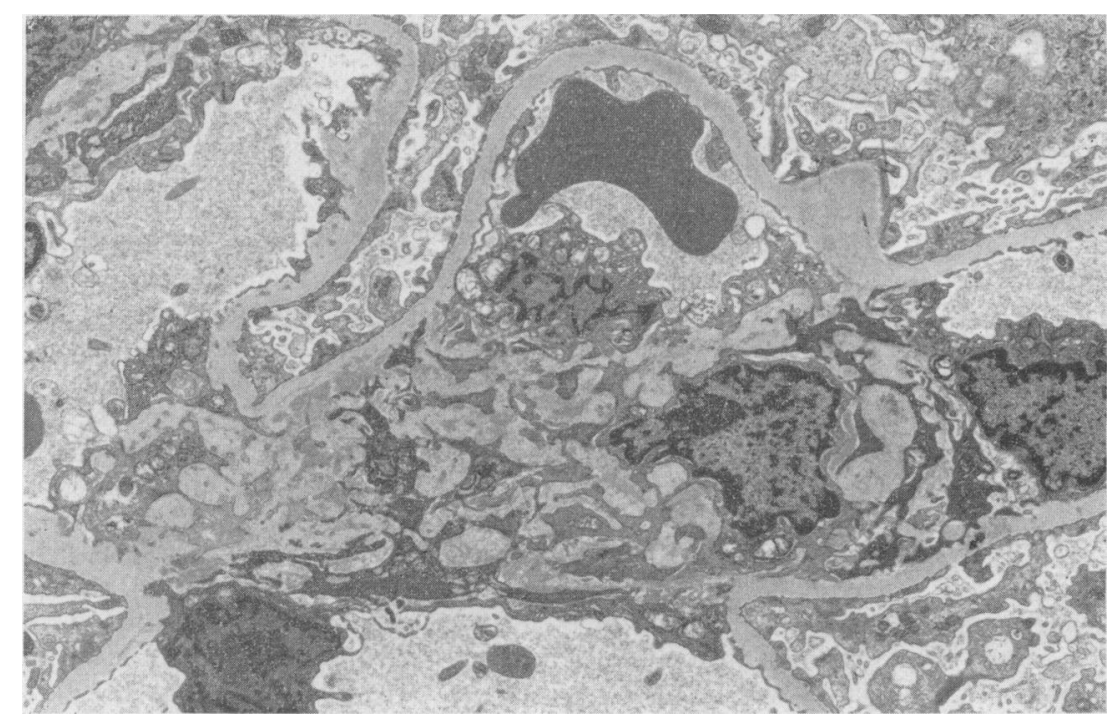

FIG. 2. Electron micrograph of part of the same glomerulus as in Fig. 1. The mesangium is expanded and contains collections of electron dense material (lead citrate, $\times 4320$ ). 
She was then placed on prednisolone $40 \mathrm{mg}$ daily. Her symptoms benefitted immediately and 6 weeks after starting therapy her respiratory function showed marked improvement with FVC, 2.17 litre; $\mathrm{FEV}_{1}, 1.95$ litre; $\mathrm{FEV}_{1} / \mathrm{FVC}, 90 \%$; slow VC, 2.33 litre; FRC, 2.21 litre; TLC, 3.62 litre. The ESR had fallen to $23 \mathrm{~mm} / \mathrm{hr}$ and her 24 -hr urinary protein excretion reduced to $0.06 \mathrm{~g}$. Complement levels remained depressed with $\mathrm{C}_{3}, 0.4 \mathrm{~g} / \mathrm{l}$; and $\mathrm{C}_{4}, 0.2 \mathrm{~g} / \mathrm{l}$.

\section{Discussion}

This further adds to evidence reported from several American centres (Bennett and Spargo, 1977; Farber and Bole, 1975; Fuller et al., 1977; Hench, Edgington and Tan, 1975; Leibfarth, McChesney and Persellin, 1975; Tan, Northway and Pinnas, 1973; Venkateswara et al., 1976) and recently from Paris (Gaudreau et al., 1978) that renal involvement does occur in MCTD. The case reported here is all the more unusual as, of those reported cases, only that by Fuller et al. (1977) was definitely associated with hypocomplementaemia, the usual finding being normal or raised complement levels.

In keeping with other connective tissue disorders renal biopsy specimens in MCTD have not shown a constant histological pattern. Of those reported membranous glomerulonephritis was recognized in 3 cases by Bennett and Spargo (1977) and one case each by Hench et al. (1975) and Fuller et al. (1977) although the latter also contained some focal mesangial proliferative changes. Venkateswara et al. (1976) reported a case with focal mesangial proliferative changes, and single cases of Leibfarth et al. (1975) and Tan et al. (1973) revealed focal proliferative and proliferative glomerulonephritic changes respectively. All these cases had glomerular deposits of complement and immunoglobulin.

It is perhaps too early to assess the significance of glomerulonephritis in MCTD as the number of cases has been small and this syndrome only accepted as a distinct entity since the original description of 25 cases by Sharp et al., in Feburary 1972. In this initial description, however, it was considered that ENA may exert a renal protective role. This was based on the finding in an earlier study by Sharp et al. (1971) that renal involvement in SLE was less aggressive and more amenable to treatment in the presence of ENA. Since then it has been shown that ENA consists of at least 2 main components, namely Sm* and RNP. As it is the latter which is present in MCTD and the former more often in SLE, the precise role of these components with regard to renal disease is therefore unclear.

MCTD is nonetheless still considered as carrying

\footnotetext{
* Smith
}

a better prognosis than any of its single constituents despite the acceptance of the occurrence of renal disease. The significance of the glomerulonephritis may only be known, therefore, with longer term follow-up of cases and increased recognition of this syndrome.

A further point of interst in the case described here is of presumed SLE in 2 sisters. Recent observations have suggested a familial association of MCTD with SLE (Sharp, 1971) and in one family MCTD was diagnosed in 2 siblings with identical HLA genotypes (Horn, Kapur and Walker, 1978).

Finally, the response to steroids of the PSS component of this syndrome is well illustrated here by the significant improvement in respiratory function in lung biopsy-proved systemic sclerosis.

\section{Acknowledgments}

ENA estimations were kindly performed by the Department of Immunology, Royal Postgraduate Medical School, Hammersmith.

\section{References}

Bennetr, R.M. \& Spargo, B.H. (1977) Immune complex nephropathy in mixed connective tissue disease. American Journal of Medicine, 63, 534.

FARBer, S.J. \& Bole, G.G. (1975) Clinical features of patients with antibody (Ab) to extractable nuclear antigen (E.N.A.). Arthritis and Rheumatism, 18, 397.

Fuller, T.J., Richman, A.V., Anerbach, D., Alexander, R.W., LotTenberg, R. \& Longley, S. (1977) Immunecomplex glomerulonephritis in a patient with mixed connective tissue disease. American Journal of Medicine, 62, 761.

Gaudreau, T.J., Amor, B., Kahn, M.S., Ryckewaert, A., SANy, J. \& Peltier, A.P. (1978) Clinical significance of antibodies to soluble extractable nuclear antigens (AntiENA). Annals of the Rheumatic Diseases, 37, 321 .

Hench, P.K., Edgington, T.S. \& TAN, E.M. (1975). The evolving clinical spectrum of mixed connective tissue disease (M.C.T.D.). Arthritis and Rheumatism, 18, 404.

Horn, J.R., Kapur, J.J. \& Walker, S.E. (1978) Mixed connective tissue disease in siblings, Arthritis and Rheumatism, 21, 709 .

Leibfarth, J.H., McChesney, L.F. \& Persellin, R.H. (1975) Characteristics of patients with high titre antibodies to extractable nuclear antigens (E.N.A.). Arthritis and Rheumatism, 18, 410.

SharP, G.C. (1971) Autoantibodies and complement in S.L.E.: a re-examination. Hospital Practice, 6, 109.

Sharp, G.C., Irvin, W.S., La RoQue, R.L., Velez, C., Daly, V., Kaiser, A.D. \& Holman, A.R. (1971) Association of autoantibodies to different nuclear antigens with clinical patterns of rheumatic disease and responsiveness to therapy. Journal of Clinical Investigation, 50, 350.

Sharp, G.C., Irvin, G.S., Tan, E.M., Gould, R.G. \& Holman, H.R. (1972) Mixed connective tissue disease. An apparently distinct rheumatic disease syndrome. American Journal of Medicine, 52, 148.

Tan, E.M., Northway. J.D. \& Pinnas, J.L. (1973) The clinical significance of antinuclear antibodies. Postgraduate Medicine, 54, 143.

Venkateswara, R.K., Berskseth, R.O., Crosson, J T., RaIJ, L. \& ShapiRo, F.L. (1976) Immune complex nephritis in M.C.T.D. Annals of Internal Medicine, 84, 174. 